\title{
II. 立体拡大撮影技術について
}

\section{座長 木内繁夫（山形大学医学部付属病院）}

1. 立体撮影における 2 焦点間距離の立体像におよぼす 效果について

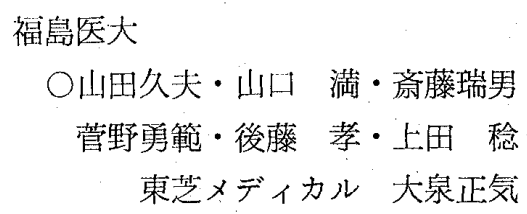

最近立体撮影が普及し, 立体撮影用X線管が内外数社 から発表されている。それらの 2 焦点間距離はそれぞれ 異なっている：そ机らの違いが立体感汇影響をおよに゙す ことは多くの人の認めることであると思われる。では実 際にどの程度の影響を与えるかを，実験的にたしかめた。 観察者の瞳孔間距離に比べて短かい 2 焦点間距離での撮 影は立体像の Z軸を圧縮する効果をもつ, 観察者の瞳孔 間距離と 2 焦点間距離が等しく, 撮影, 観察距離が等し く,フィルムの配置誤差のないという条件のもとでは, 実際の $Z$ 軸之立体像の $Z$ 軸が 1 対 1 の対応沉なる, 即ち 歪の最少の立体像が得られる.

\section{2. 立体拡大撮影像の光学的拡大観察}

(株)島津製作所医用機器事業部 ○小沢聑史・武本 肇 京都放射線技術専門学校 中堀孝志

立体拡大撮影された像の光学的拡大観察について述べ る. 笔者らが開発した立体拡大撮影システムにおいて観 察距離は $70 \mathrm{~cm}$ である. これは大角版のフィルム上の像 を全体としてとらえるのに適した距離として採用した。 像の一部分をより詳細に観察しようとする場合はさらに 近い観察距離の方が有利である。しかしながら，立体視 しながら観察距離を小さくしてゆくと観察像の高さ方向 の情報も同時に小さくなって，像注押しつぶされた形に なる。乙れを解決するために，観察距離は $70 \mathrm{~cm}$ 一定の まま像だけ拡大して観察する方法を考察した，乙の方法 によれば立体拡大摄影した像をさらに拡大して観察する ことができ，なおかつ観察像と被写体とは三次元的に相 似である。

実際には立体観察鏡に簡単な光学系を追加するととに より，てれが実現できる。乙の光学系は一定倍率拡大し た像を，目より $70 \mathrm{~cm}$ 離れた位置作るととを特徵とす る. との光学系を通すととにより, 被写体汇近づいて観
察するの之同様の效果が得られる.

以上のような考えに基づいて光学系を試作し，実際に 立体観察鏡に取り付けて立体拡大撮影された血管造影像 を観察した結果，非常に細い血管の三次元的な位置関係 および走行をはっきり之認識するてとができた。また， 観察像上被写体との三次元的な相似性についてはテスト モデルを撮影し，それを観察して確認するとともに，理 論的にも炋明できた。

\section{3. 立体拡大撮影における焦点サイズおよび焦点間隔距} 離

愛知県がんセンター病院放射線科第 1 部技術科 ○堀田勝平・長谷川脣一・内藤光利 安部忠夫・岩根 茂

〔目的〕立体拡大連続撮影管球の焦点サイズの調整抏 よび焦点間隔距離のちがいによる識別能と立体感につい て検話した.

〔万法・結果〕焦点サイズの調整は，管電流を変化さ せて，スターチャートを拡大率 2 倍で測定した。管電流 を下げることにより小さくできた.

識別能は Buerger's Phantom を使用して比較した。 焦点間隔は， $25 \mathrm{~mm}$ と $50 \mathrm{~mm}$ の立体拡大撮影と焦点閒 隔 $100 \mathrm{~mm}$ の非立体拡大撮影である. 立体掋大撮影は, 拡大しない立体撮影にくらべて識別能は上く，焦点間隔 $50 \mathrm{~mm}$ がー一番識別できた.

立体感は階段チャートを撮影した立体像と自作スケー ルによって, 視覚深度を測定した。

計測値は，ほぼ同じ值を示した。

〔考察〕立体拡大撮影管球の容量が允分であれば管電 流を下げても焦点を小さくすべきと考える。

焦点間隔のちがい忙よる立体感は，立体拡大で $25 \mathrm{~mm}$ 非立体拡大で $100 \mathrm{~mm}$ の焦点間隔で同じ深度であるが, 実際には FFD/m で 2 管球の非立体拡大は不可能であり, われわれの所では FFD $125 \mathrm{~cm}$ で焦点間隔が $18 \mathrm{~cm}$ の 非立体拡大像に比べて奥行が浅く感じられる，立体拡大 撮影では焦点間隔 $50 \mathrm{~mm}$ は, 奥行が $25 \mathrm{~mm}$ 亿対して 2 倍となり，小さな奥行む分離しやすい。

自作スケールは，製作が簡単で立体像を議論するのに 非常汇有益であった。 